\title{
Effect of crystallization on wear and corrosion behavior of electroless Ni-P/Ni-B duplex coating on ferrous PM compacts
}

\author{
U. Matik* \\ Department of Machine and Metal Technologies, Karabuk University, 78050 Karabuk, Turkey
}

Received 4 November 2019, received in revised form 28 April 2020, accepted 14 May 2020

\begin{abstract}
This paper investigates the effect of crystallization on wear and corrosion behavior of the electroless Ni-P/Ni-B duplex coatings on ferrous PM compacts. The PM compacts were plated with Ni-P and Ni-B by the electroless deposition method. The duplex coated samples were heat-treated at 300 and $420^{\circ} \mathrm{C}$ for $1 \mathrm{~h}$, according to the major crystallization temperatures of the coatings. Samples were examined and characterized by DSC, XRD, and SEM. Wear tests were performed by using a pin-on-disc tribometer under $30 \mathrm{~N}$ normal load. Electrochemical corrosion tests were also carried out. XRD patterns reveal that the structure of the as-plated $\mathrm{Ni}-\mathrm{P} / \mathrm{Ni}-\mathrm{B}$ coating is amorphous. Heat treatments caused an increment in the hardness and wear resistance of coatings due to precipitation hardening by the formation of the hard phase. It was also found that the as-plated coating shows better corrosion performance in comparison with the crystallized coatings.
\end{abstract}

K e y w o r d s: electroless, crystallization, heat treatment, hardness, wear, friction

\section{Introduction}

The ferrous PM compacts usually face such working conditions as involving abrasion, rolling, and sliding [1]. Therefore, good wear resistance is a significant mechanical property expected from these parts in actual service conditions [2]. There are some studies to enhance surface hardness, wear, and corrosion resistance of PM parts with electroless deposition method $[3,4]$. However, these studies were limited to electroless Ni-P based alloy and composite coatings [5-7].

Electroless metal plating is an autocatalytic process that proceeds following the electrochemical kinetic principles [8]. Electroless nickel has been utilized extensively in the engineering industry as a process that protects parts against abrasive and corrosive conditions. Hypophosphite-reduced electroless Ni-P plating has proved its supremacy in providing improved hardness, corrosion, and wear resistance. The principal advantages of borohydride-reduced electroless $\mathrm{Ni}-\mathrm{B}$ deposits are their hardness and superior wear resistance in the as-plated condition. Electroless Ni-B coatings distinguish from their phosphorus-based counterparts by its higher hardness, which can still be increased by well chosen heat treatment, higher wear resistance, and better adhesion, but they usually present a lesser corrosion resistance [9]. Comparing with single layer electroless $\mathrm{Ni}-\mathrm{P}$ or Ni-B coatings, electroless duplex coatings have higher corrosion and wear resistance. High hardness, wear, and corrosion resistance is the primary reason for the $\mathrm{Ni}-\mathrm{B}$ coatings usage [10-13]. However, Ni-B coating as an outer layer after Ni-P coating gives better results when high hardness and wear resistance, as well as corrosion resistance are required $[9,14,15]$. The high boron content Ni-B coatings offer high hardness and superior wear resistance in the as-plated condition [16, 17]. Also, heat treatment strongly influences the electroless nickel coatings structure and, thus, the corrosion properties of the coatings [18-20].

In this study, the heat treatment effect was examined on structure, hardness, wear, and corrosion resistance of the electroless $\mathrm{Ni}-\mathrm{P} / \mathrm{Ni}-\mathrm{B}$ duplex coated PM compacts subjected to isothermal heat treatment according to the crystallization temperatures of the coatings.

*Corresponding author: tel.: +90 370 4189427; fax: +90 370 4189345; e-mail address: matik@karabuk.edu.tr 
Table 1. The procedures of the surface preparation and electroless deposition processes

\begin{tabular}{|c|c|c|c|c|}
\hline Process & Operation & Composition & & Conditions \\
\hline 1 & Grinding & $\mathrm{SiC}$ paper up to 4000 grit & & \\
\hline 2 & Alkaline cleaning & $\begin{array}{l}\mathrm{NaOH} \\
\mathrm{Na}_{3} \mathrm{PO}_{4}\end{array}$ & $\begin{array}{l}50 \mathrm{~g} \mathrm{l}^{-1} \\
10 \mathrm{~g} \mathrm{l}^{-1}\end{array}$ & $\begin{array}{l}\text { Temperature } 60^{\circ} \mathrm{C} \\
\text { Time } 1 \mathrm{~min}\end{array}$ \\
\hline 3 & Acid etching & $\mathrm{HNO}_{3}$ & $30 \mathrm{ml} \mathrm{l}^{-1}$ & Time $10 \mathrm{~s}$ \\
\hline 4 & Electroless Ni-P & $\begin{array}{l}\text { Nickel chloride } \\
\text { Sodium hypophosphite } \\
\text { Sodium citrate } \\
\text { Ammonium chloride } \\
\text { Ammonium hydroxide solution }\end{array}$ & $\begin{array}{l}35 \mathrm{~g} \mathrm{l}^{-1} \\
10 \mathrm{~g} \mathrm{l}^{-1} \\
65 \mathrm{~g} \mathrm{l}^{-1} \\
50 \mathrm{~g} \mathrm{l}^{-1} \\
\text { for } \mathrm{pH}\end{array}$ & $\begin{array}{l}\mathrm{pH} 8.5-9 \\
\text { Temperature } 82 \pm 2{ }^{\circ} \mathrm{C} \\
\text { Time } 10 \text { min }\end{array}$ \\
\hline 5 & Electroless Ni-B & $\begin{array}{l}\text { Nickel chloride } \\
\text { Ethylenediamine } \\
\text { Sodium hydroxide } \\
\text { Sodium borohydride } \\
\text { Thallium acetate }\end{array}$ & $\begin{array}{l}30 \mathrm{~g} \mathrm{l}^{-1} \\
90 \mathrm{~g} \mathrm{l}^{-1} \\
90 \mathrm{~g} \mathrm{l}^{-1} \\
1.2 \mathrm{~g} \mathrm{l}^{-1} \\
14 \mathrm{mg} \mathrm{l}^{-1}\end{array}$ & $\begin{array}{l}\mathrm{pH} 13-14 \\
\text { Temperature } 95 \pm 2^{\circ} \mathrm{C} \\
\text { Time } 90 \text { min }\end{array}$ \\
\hline
\end{tabular}

\section{Materials and methods}

The ferrous PM compacts were produced by using Höganäs ASC 100.29 atomized iron powders mixture with an addition of 0.5 wt. $\%$ graphite by the conventional powder metallurgy manufacturing technique. The iron and graphite powders were blended homogeneously by using a shaker-mixer (Turbula T2F). After blending, the powders were pressed into cylindrical compacts with $12 \mathrm{~mm}$ diameter and $12 \mathrm{~mm}$ height under $800 \mathrm{MPa}$ pressure for $10 \mathrm{~s}$. The green compacts were sintered under flowing argon atmosphere at $1120^{\circ} \mathrm{C}$ for $45 \mathrm{~min}$ with the heating and cooling rates of $10^{\circ} \mathrm{C} \mathrm{min}^{-1}$. Sintered densities of the specimens were measured by the Archimedes' method.

Before coating processes, the surface preparation procedures were applied to specimens. The procedures of the surface preparation and electroless deposition processes on the ferrous PM compacts are shown in Table 1. After the surface preparation, the Ni-P coated samples were rinsed with deionized water at $80^{\circ} \mathrm{C}$ for $10 \mathrm{~s}$ and then transferred immediately to the Ni-B bath. As the mechanical properties are more important in PM compacts, Ni-B coating was applied as a thicker layer with better hardness and abrasion resistance than Ni-P coatings.

Some of the coated samples were heat-treated at distinct temperatures $\left(300\right.$ and $\left.420^{\circ} \mathrm{C}\right)$ for $1 \mathrm{~h}$ to specify the phase transformation effect on the structure, hardness, wear, and corrosion resistance of the samples. Heat treatments were carried out in the air without a protective atmosphere.

The duplex coating morphology was performed by utilizing SEM (Carl Zeiss ULTRA FESEM equipped with EDX). The crystallization temperature of the coatings was detected by differential scanning calorimetry (DSC) in Hitachi DSC7000X. The structure of the as-plated and heat-treated coatings was characterized by XRD (Rigaku Ultra IV XRD) with $\mathrm{Cu} \mathrm{K} \alpha$ radiation $(k=1.5406 \AA)$ at a scan rate of $0.06^{\circ} \mathrm{s}^{-1}$ in the range of $20^{\circ}-80^{\circ}$ and $0.01^{\circ}$ step size. Hardness measurements were carried out by employing a load of $100 \mathrm{gf}$ on cross-sections of coatings using a microhardness tester (Qness Q10) equipped with Vickers indenter. The wear behavior of the uncoated and coated pin samples was investigated by using a pin-on-disc type apparatus (UTS Tribometer T10/20). Specific wear rate and friction coefficient values were determined with an applied load of $30 \mathrm{~N}$ and a constant sliding velocity of $1 \mathrm{~ms}^{-1}$ in a sliding distance of $1000 \mathrm{~m}$. AISI 52100 steel with hardness $62 \mathrm{HRC}$ was used as a counter-disc. The corrosion resistance was studied by the Tafel polarization test in a $3.5 \% \mathrm{NaCl}$ solution. Electrochemical measurements were performed using a Parstat 4000 potentiostat/galvanostat system. The Tafel potential and corrosion current density were determined by extrapolating the straight-line section of the anodic and cathodic Tafel lines by using Versa Studio software.

\section{Results and discussion}

\subsection{Microstructure and phase composition}

The density measurements indicate that the PM compacts have a porosity of about $5.5 \%$. However, the amount of the porosity on the outer surface region of the cylindrical compacts was determined below $3 \%$ by using an optical microscope (Nikon MA200) and im- 

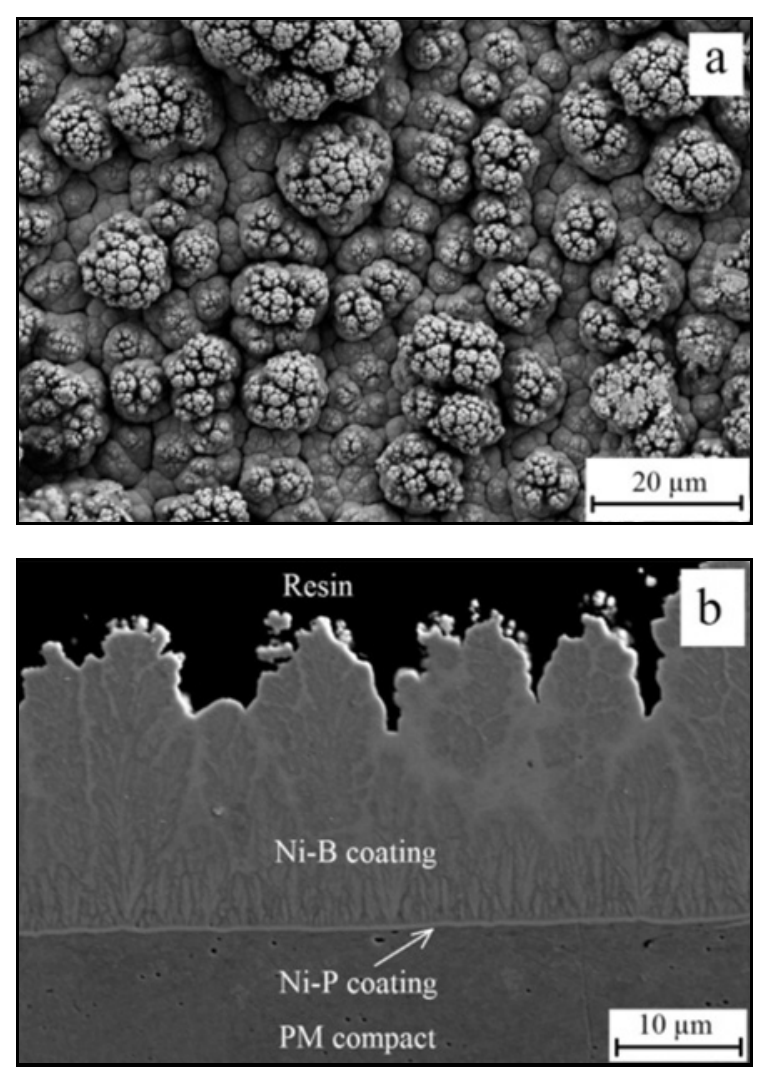

Fig. 1. SEM images of (a) the surface and (b) cross-section of $\mathrm{Ni}-\mathrm{P} / \mathrm{Ni}-\mathrm{B}$ coating.

age analysis software. The density and porosity distribution in the PM compacts are generally not homogeneous due to the frictional forces between particles and between the powder and the die walls [21]. Therefore, in the present study, the tests were applied to the top surfaces of the PM compacts with a high density due to eliminating the negative effects of porosity in the PM compacts.

The surface and cross-section morphologies of the as-plated duplex coating on the ferrous PM substrate are presented in Fig. 1. The Ni-B coatings have a columnar morphology (Fig. 1b) and quite rough and a cauliflower-like surface (Fig. 1a) [18, $22,23]$. Literature reports show that the cauliflowerlike morphology makes the Ni-B coating natural lubricant and improves the wear resistance by reducing the contact surface area [24-26]. The chemical tests show that the Ni-P coating contains P 4.8 wt.\% and $\mathrm{Ni} 95.2$ wt.\%, whereas the Ni-B coating contains 5.7 wt.\% B-94.3 wt.\% Ni. It is evident from Fig. 1b that Ni-P coating is uniform and the compatibility of the Ni-B and PM compact is good. The thickness of Ni-P coatings is about $0.43 \mu \mathrm{m}$ for a deposition time of $10 \mathrm{~min}$ and $20 \mu \mathrm{m}$ of Ni-B coating for a deposition time of $90 \mathrm{~min}$. However, in the columnar regions where the growth in the Ni-B coat-
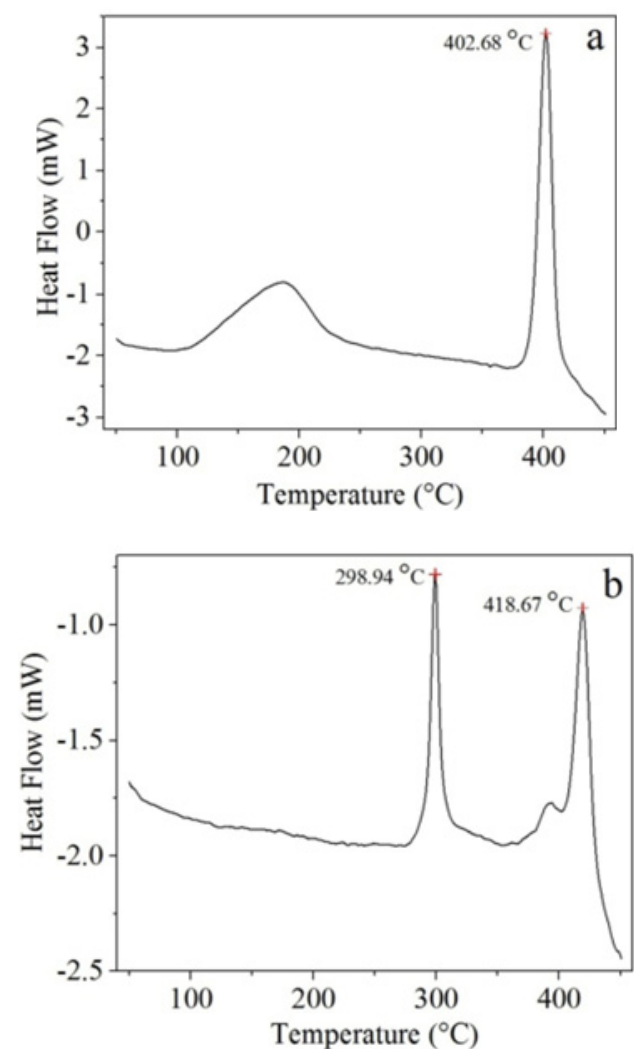

Fig. 2. Differential curves of (a) Ni-P and (b) Ni-B coatings at a heating rate of $10^{\circ} \mathrm{C} \mathrm{min}-1$.

ing is faster, the coating thickness is seen to reach $27 \mu \mathrm{m}$.

\subsection{Characterization of phase transformation}

The crystallization behavior of the electroless Ni-P and Ni-B films was analyzed only for the films acquired in the coating baths in Table 1. The DSC traces of Ni-P and Ni-B coatings were acquired under similar conditions. The crystallization peak temperature of the Ni-P coating determined from the major exothermic peak of the DSC curve was $402.68^{\circ} \mathrm{C}$ (Fig. 2a). DSC curve of Ni-B coating exhibited two exothermic peaks at 298.94 and $418.67^{\circ} \mathrm{C}$ (Fig. 2b). According to phase transformation via exothermic reactions of the films, two different heat treatment temperatures (300 and $420^{\circ} \mathrm{C}$ ) were determined to effects of crystallization on the properties of the duplex coating. The phases formed in the coatings were determined by XRD analysis.

Figure 3 compares the X-ray diffraction patterns of the coating surfaces for as-plated and heat-treated coatings. The XRD pattern of the as-plated samples displays a single broad peak indicative of the amorphous phase with a very small amount of crystalline Ni. Heat treatment at $420^{\circ} \mathrm{C}$ for $1 \mathrm{~h}$ causes the crys- 

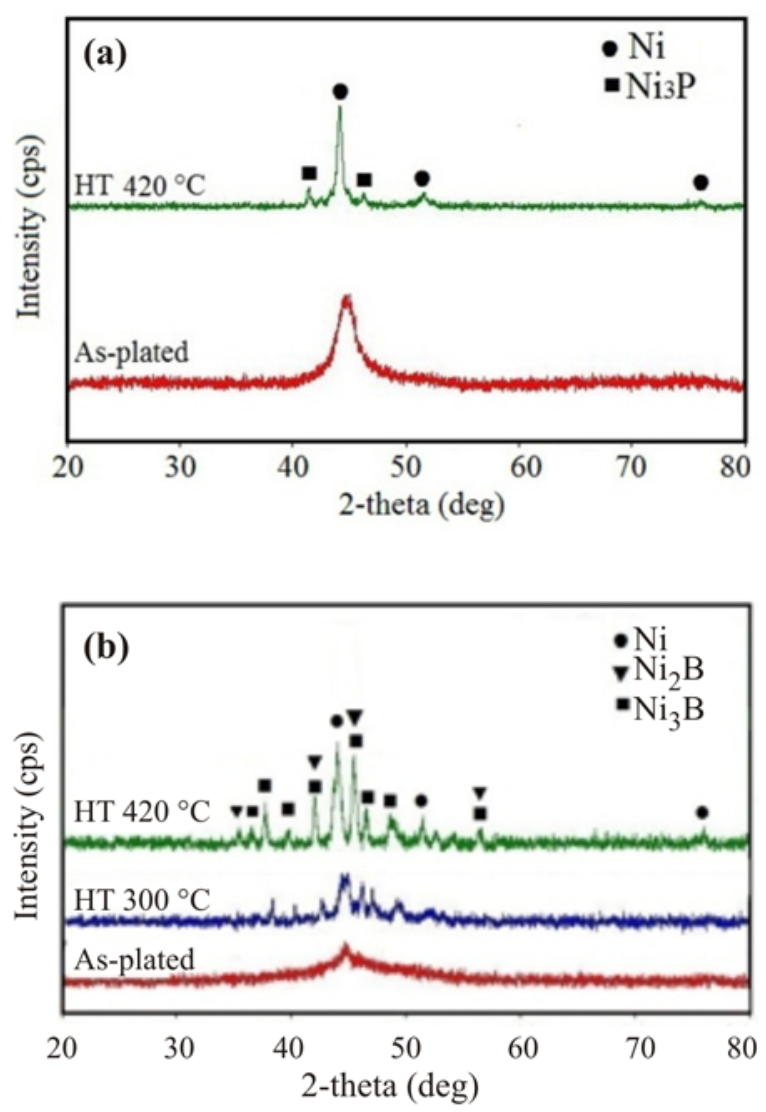

Fig. 3. XRD patterns of the as-plated and heat-treated coatings (a) Ni-P and (b) Ni-B.

tallization of the $\mathrm{Ni}-\mathrm{P}$ coating and the $\mathrm{Ni}$ - and $\mathrm{Ni}_{3} \mathrm{P}$ -phases. Heat treatment at $300{ }^{\circ} \mathrm{C}$ for $1 \mathrm{~h}$ causes the crystallization of the $\mathrm{Ni}-\mathrm{B}$ coating and the $\mathrm{Ni}$ - and $\mathrm{Ni}_{3} \mathrm{~B}$-phases. Heating to $420^{\circ} \mathrm{C}$ for $1 \mathrm{~h}$ leads to a further sharpening of the $\mathrm{Ni}$ and $\mathrm{Ni}_{3} \mathrm{~B}$ reflections and the formation of the $\mathrm{Ni}_{2} \mathrm{~B}$-phase. In the XRD analysis of the duplex coating surfaces, the peaks of the inner layer Ni-P-phases could not be detected.

\subsection{Microhardness}

The microhardness variations with heat treatments are presented in Fig. 4. The hardness of heat-treated Ni-B coating shows that coating hardness increases with heat treatment temperature and reaches the peak value $\left(1124 \mathrm{HV}_{100}\right)$ at $420^{\circ} \mathrm{C}$ due to precipitation hardening by the formation of intermetallic $\mathrm{Ni}_{3} \mathrm{~B}$ - and $\mathrm{Ni}_{2} \mathrm{~B}$-phases. The hardness of the Ni-P coating is not measurable because the coating thickness is too thin. Still, in the previous work [27], the hardness of the $\mathrm{Ni}-\mathrm{P}$ coating made with the same solution, as-plated and heat-treated coating at $400{ }^{\circ} \mathrm{C}$ are $650 \mathrm{HV}_{100}$ and $1030 \mathrm{HV}_{100}$, respectively. In the case of heat-treated $\mathrm{Ni}-\mathrm{P}$ coating at $400^{\circ} \mathrm{C}$, the formation of intermetallic $\mathrm{Ni}_{3} \mathrm{P}$ causes an increment in the hardness of coating $[5,27]$.

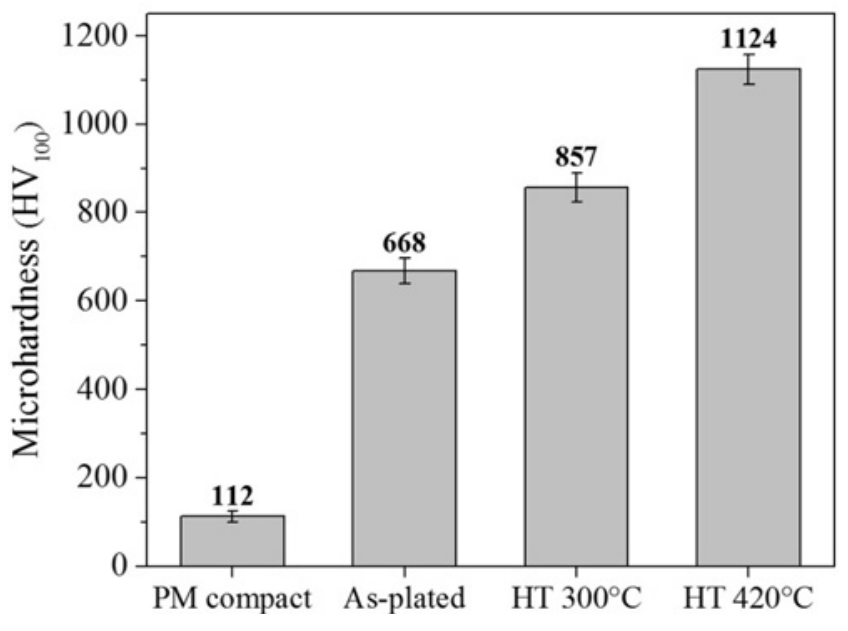

Fig. 4. The microhardness of the samples.

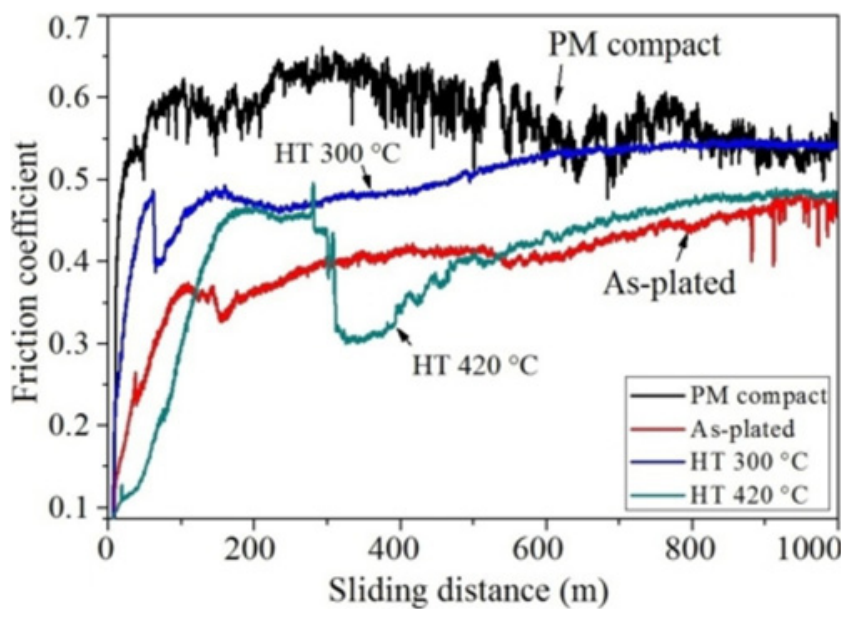

Fig. 5. The coefficient of friction of the samples under $30 \mathrm{~N}$.

Ta ble 2. Average wear rate and coefficient of friction of $\mathrm{PM}$ compact and the coatings

\begin{tabular}{lcc}
\hline Sample & Coefficient of friction, $\mu_{\text {av }}$ & Wear loss $(\mathrm{mg})$ \\
\hline PM compact & 0.53 & 48.1 \\
As-plated & 0.40 & 18.3 \\
HT $300^{\circ} \mathrm{C}$ & 0.43 & 10.1 \\
HT $420^{\circ} \mathrm{C}$ & 0.39 & 3.7 \\
\hline
\end{tabular}

\subsection{Wear and friction analysis}

The average friction coefficients $\left(\mu_{\mathrm{av}}\right)$ and wear losses of PM compact, and Ni-P/Ni-B coatings are given in Table 2. The friction coefficients of the samples exhibit an initial sharp increase (Fig. 5). The friction coefficient of PM compacts indicated an increas- 

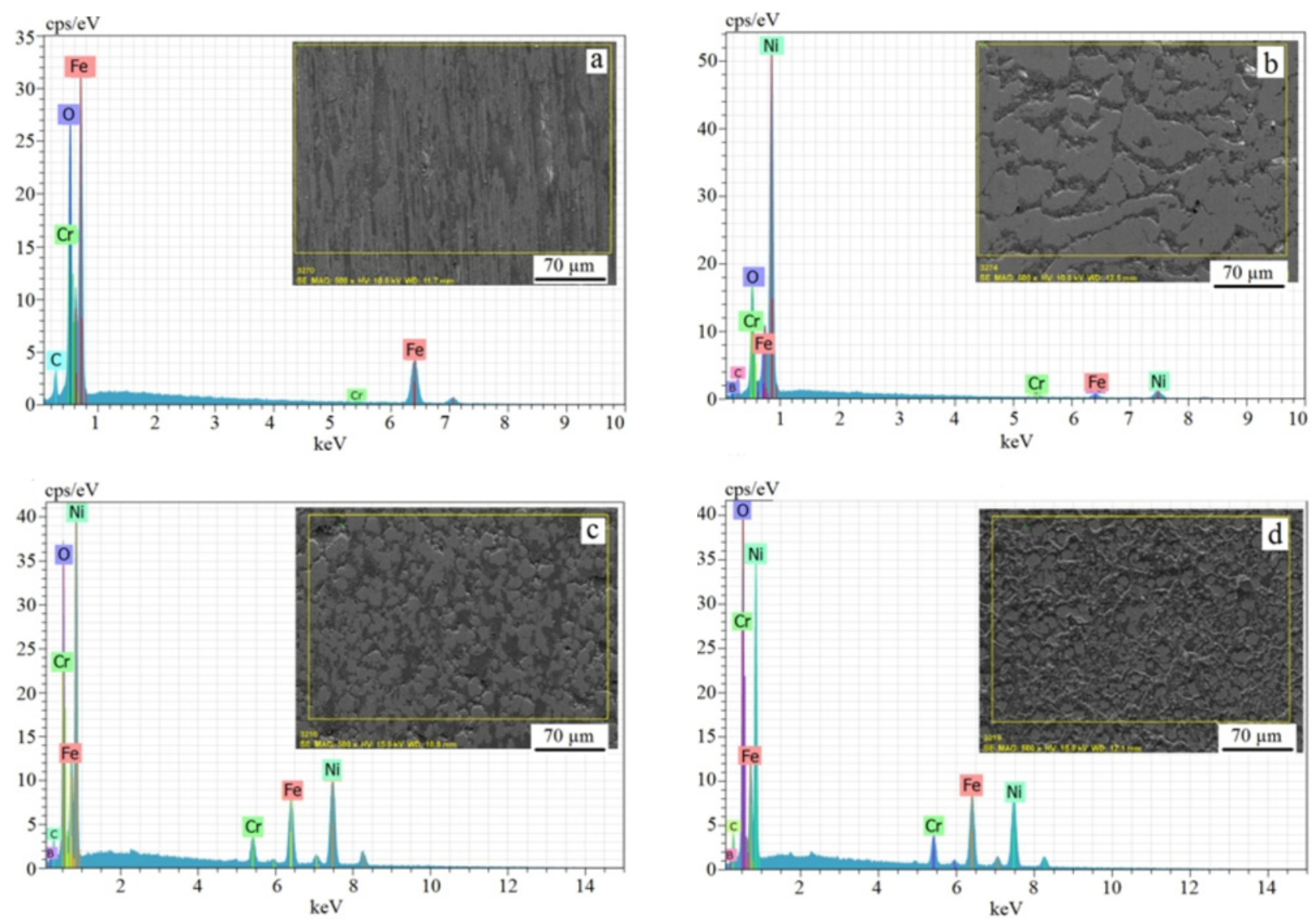

Fig. 6. EDX area analysis of the wear tracks on the samples (a) PM compact, (b) as-plated, (c) $\mathrm{HT} 300^{\circ} \mathrm{C}$, and (d) $\mathrm{HT}$ $420^{\circ} \mathrm{C}$.

ing tendency in the initial phase of the wear test, followed by a decreasing trend. The decreasing trend of the PM compacts' coefficient of friction may be caused by the oxide layers formed as a result of frictional heating (Fig. 6a). After the initial phase of the wear test, the friction coefficient of the coatings follows a fluctuating course between 80 and $500 \mathrm{~m}$, then, they increase until about $800 \mathrm{~m}$ where it becomes stable. These fluctuating courses in the friction coefficients of all coatings can be explained by the alteration of the contact surface area and trapped materials on the rough surface of the coating. The fluctuations in the friction coefficients can be explained by $\mathrm{Fe}$ and $\mathrm{Cr}$ existence on the worn surface of coatings (Figs. 6b-e). EDX analyses proved that material transfers from contra disc (AISI 52100) to PM compact surfaces were too low, and the dark regions in SEM images were oxidized zones (Fig. 6a). EDX analysis of the worn surface of the coatings reveals the transferred material from the counter disc to the worn surfaces of the coatings (Figs. 6b-e). The average friction coefficient is less for as-plated and heat-treated $\mathrm{Ni}-\mathrm{P} / \mathrm{Ni}-\mathrm{B}$ coating at $420^{\circ} \mathrm{C}$ compared to that of acquired for heat-treated others. Wear loss decreases with heat treatment temperature up to $420^{\circ} \mathrm{C}$, above which it slightly increases
(Table 2). The decrease in wear loss with increasing heat treatment temperature is due to the precipitation of hard $\mathrm{Ni}_{3} \mathrm{~B}$ - and $\mathrm{Ni}_{2} \mathrm{~B}$-phases, which is confirmed by the XRD measurement (see Fig. 3). Finally, the heat-treated Ni-P/Ni-B coating at $420^{\circ} \mathrm{C}$ exhibits enhanced wear resistance and lesser friction coefficient than other samples. However, it is thought that the transferred material from the disc substantially influences the friction and wear properties of the coatings.

The surface morphologies obtained by SEM from the worn area of PM compact and Ni-P/Ni-B coatings are presented in Fig. 6. It is seen that the wear track of PM compact shows deep grooves generated along the sliding direction (Fig. 6a). Besides, the oxide layer formations were detected on the worn surface of PM compacts. The SEM images of as-plated and heattreated coatings also show that almost all the coating remained on the heat-treated samples (Figs. 6b-e). The heat treatments are generally used to improve the coating adhesion. Therefore, the wear resistance increases as a result of improving bond strength between coating and PM compact and increasing the hardness of the coating by precipitation. SEM images also show that the transferred patches from the counter disc and the wear debris present on the surface of all the coat- 


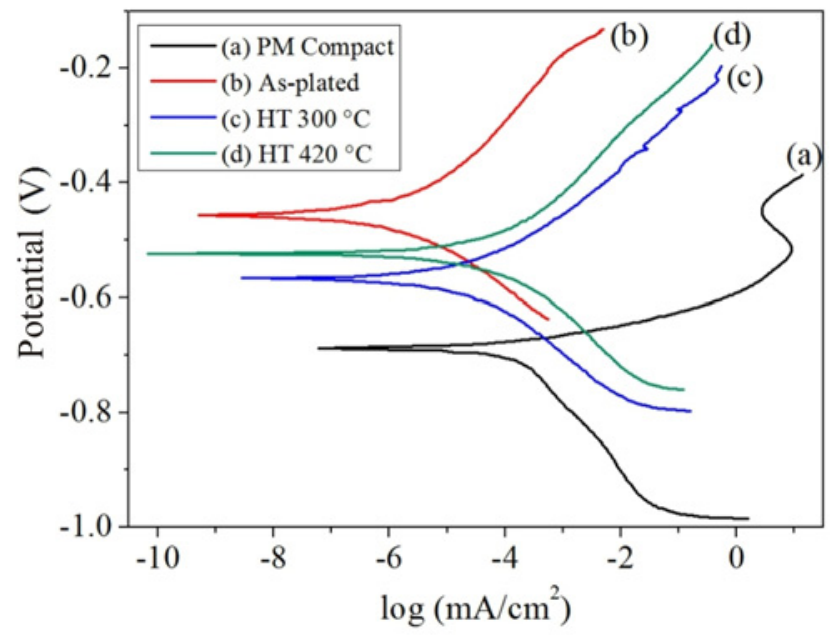

Fig. 7. Polarization curves of the samples in a $3.5 \%$ aqueous $\mathrm{NaCl}$ solution.

ings indicate the occurrence of adhesion between them (Figs. 6b-e).

\subsection{Corrosion properties}

Figure 8 presents the comparison of the polariza-
Table 3. Electrochemical corrosion parameters of PM compact and the coatings in $3.5 \% \mathrm{NaCl}$ solution

\begin{tabular}{lcc}
\hline Sample & $E_{\text {corr }}(\mathrm{mV})$ & $I_{\text {corr }}\left(\mu \mathrm{A} \mathrm{cm}^{-2}\right)$ \\
\hline PM compact & -686.75 & 25.09 \\
As-plated & -451.25 & 2.35 \\
HT 300 ${ }^{\circ} \mathrm{C}$ & -566.92 & 14.92 \\
HT $420^{\circ} \mathrm{C}$ & -519.82 & 26.23 \\
\hline
\end{tabular}

tion curves of $\mathrm{PM}$ compact and $\mathrm{Ni}-\mathrm{P} / \mathrm{Ni}-\mathrm{B}$ coatings in a $3.5 \% \mathrm{NaCl}$ solution. As it is evident from the polarization curves, the anodic-cathodic polarization Tafel line of the Ni-P/Ni-B coatings was acquired at positive corrosion potentials and lower corrosion current densities than that of PM compact sample. It has also been found that as-plated $\mathrm{Ni}-\mathrm{P} / \mathrm{Ni}-\mathrm{B}$ coating has the lowest current density. This result indicates that $\mathrm{Ni}-\mathrm{P} / \mathrm{Ni}-\mathrm{B}$ coatings increase the corrosion resistance of the PM compact significantly, and the as-plated $\mathrm{Ni}-\mathrm{P} / \mathrm{Ni}-\mathrm{B}$ coated sample has the highest corrosion resistance. The electrochemical corrosion parameters derived from the polarization curves and corrosion rates of the samples were presented in Table 3 to verify this result. In the heat-treated $\mathrm{Ni}-\mathrm{B}$ coatings at 300 and $420^{\circ} \mathrm{C}$, the corrosion resistance decreases due to the
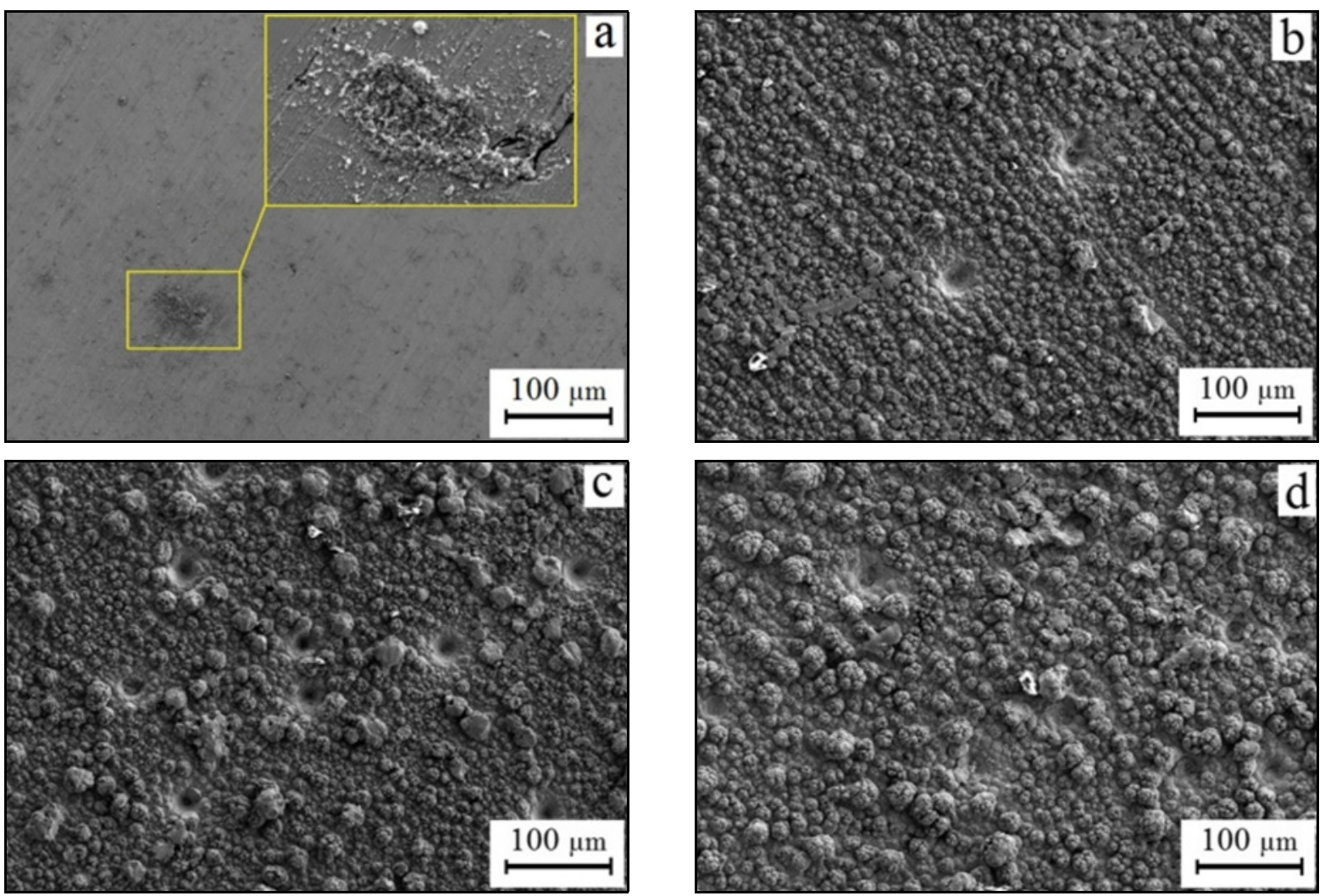

Fig. 8. Corroded surfaces of the samples (a) PM compact, (b) as-plated, (c) HT $300^{\circ} \mathrm{C}$, and (d) $\mathrm{HT} 420^{\circ} \mathrm{C}$. 
increase in heat treatment temperature. The decrease in corrosion resistance with heat treatment temperature increase up to $420^{\circ} \mathrm{C}$ is due to the precipitation of $\mathrm{Ni}_{3} \mathrm{~B}$ and $\mathrm{Ni}_{2} \mathrm{~B}$ into the nickel matrix and decreasing the amorphous phase in the coating. The crystalline nickel and nickel-boride phases lead to the formation of zones with different corrosion potentials within the coating structure. These zones reduce the corrosion resistance of the coating by acting as active/passive galvanic cells [28]. It has also been thought that Ni-P thin film applied before Ni-B coating process affects corrosion resistance of all coated samples positively. When the corroded surfaces of the samples were examined, it was found that the corrosion occurring in the as-plated and $\mathrm{HT} 300^{\circ} \mathrm{C}$ samples was pitting corrosion (Figs. 8b, c). In HT $420^{\circ} \mathrm{C}$ sample, pitting and general corrosion were observed (Fig. 8d).

\section{Conclusions}

In the present study, the effects of heat treatment on morphology, structure, microhardness, frictional behavior, and wear resistance of the electroless Ni-P/Ni-B duplex coating on ferrous PM compacts were investigated. The following results were obtained:

- The Ni-P/Ni-B duplex coating was successfully deposited on ferrous PM compacts by the electroless deposition method.

- The Ni-B coating has a columnar cross-section and a cauliflower-like surface morphology. The surface morphology of the Ni-B coating has improved friction and wear properties.

- The XRD patterns showed that the as-plated $\mathrm{Ni}-\mathrm{P} / \mathrm{Ni}-\mathrm{B}$ coating has a mixture of the amorphous and crystalline phases. However, the heat treatment causes the coating to turn into a crystalline structure.

- The precipitation of intermetallic compounds leads to an increase in microhardness.

The heat-treated Ni-P/Ni-B coating at $420^{\circ} \mathrm{C}$ exhibits higher wear resistance and less friction coefficient.

- The as-plated Ni-P/Ni-B coating displays better corrosion performance in comparison with the crystallized coatings.

\section{Acknowledgement}

The tests and analyses in this study were accomplished by the financial support of the Karabuk University Scientific Research Foundation (Project number: KBU-BAP-14/1-DS-058).

\section{References}

[1] S. Senthur Prabu, S. Prathiba, M. A. Asokan, A. Jain, N. K. Jain, P. K. Chourasiya, Investigations on dry sliding wear behaviour of sintered/extruded $\mathrm{P} / \mathrm{M}$ alloy steels (Fe-C-W-Ti), Procedia Eng. 97 (2014) 2119-2126. doi:10.1016/i.proeng.2014.12.455

[2] K. V. Sudhakar, P. Sampathkumaran, E. S. Dwarakadasa, Dry sliding wear in high density $\mathrm{Fe}-2 \% \mathrm{Ni}$ based P/M alloys, Wear 242 (2000) 207-212. doi:10.1016/S0043-1648(00)00422-1

[3] M. Etaat, M. Emamy, M. Ghambari, E. Fadaei, Surface treatment and nickel plating of iron powder metallurgy parts for corrosion protection, Mater. Des. 30 (2009) 3560-3565. doi:10.1016/j.matdes.2009.02.029

[4] C. Zhang, L. Kong, H. Li, Y. Wu, Electroless Cu plating on the microstructure and hardness of $\mathrm{Al}-\mathrm{Cu}$ powder metallurgy alloy, Mater. Res. Express. 6 (2019) 086577. doi:10.1088/2053-1591/ab1e1a

[5] U. Matik, Structural and wear properties of heattreated electroless Ni-P alloy and Ni-P-Si $\mathrm{N}_{4}$ composite coatings on iron based PM compacts, Surf. Coatings Technol. 302 (2016) 528-534. doi:10.1016/i.surfcoat.2016.06.054

[6] D. Singh, R. Balasubramaniam, R. K. Dube, Effect of coating time on corrosion behavior of electroless nickel-phosphorus coated powder metallurgy iron specimens, Corrosion 51 (1995) 581-585. doi:10.5006/1.3293617

[7] F. Tabatabaei, S. Vardak, S. Alirezaei, K. Raeissi, The tribocorrosion behavior of Ni-P and Ni-P-ZrO $\mathrm{Z}_{2}$ coatings, Kovove Mater. 56 (2018) 379-387. doi:10.4149/km_2018_6_379

[8] M. Urgen, Chemistry of Electroless Plating, in: F. Delaunois, V. Vitry, L. Bonin (Eds.), Electroless Nickel Plat. Fundam. to Appl., first ed., CRC Press, London, 2019. doi:10.1179/imr.1992.37.1.196

[9] T. S. N. S. Narayanan, K. Krishnaveni, S. K. Seshadri, Electroless Ni-P/Ni-B duplex coatings: Preparation and evaluation of microhardness, wear and corrosion resistance, Mater. Chem. Phys. 82 (2003) 771-779. doi:10.1016/S0254-0584(03)00390-0

[10] A. F. Kanta, V. Vitry, F. Delaunois, Effect of thermochemical and heat treatments on electroless nickelboron, Mater. Lett. 63 (2009) 2662-2665. doi:10.1016/i.matlet.2009.09.031

[11] V. Vitry, A.-F. Kanta, F. Delaunois, Mechanical and wear characterization of electroless nickel-boron coatings, Surf. Coatings Technol. 206 (2011) 1879-1885. doi:10.1016/j.surfcoat.2011.08.008

[12] A. Baibordi, K. Amini, M. H. Bina, A. Dehghan, The effect of heat treatment temperature on the properties of the composite duplex electroless coating of $\mathrm{Ni}-\mathrm{P} / \mathrm{Ni}-$ -B-BN containing boron nitride nanoparticles, Kovove Mater. 52 (2014) 263-268. doi:10.4149/km_2014_5_263

[13] S. A. Abdel-Gawad, M. A. Sadik, M. A. Shoeib, Preparation and properties of a novel nano Ni-B-Sn by electroless deposition on 7075-T6 aluminum alloy for aerospace application, J. Alloys Compd. 785 (2019) 1284-1292. doi:10.1016/j.jallcom.2019.01.245

[14] V. Vitry, A. Sens, A. F. Kanta, F. Delaunois, Wear and corrosion resistance of heat treated and as-plated duplex $\mathrm{NiP} / \mathrm{NiB}$ coatings on 2024 aluminum alloys, Surf. Coatings Technol. 206 (2012) 3421-3427. doi:10.1016/i.surfcoat.2012.01.049

[15] A. Salicio-Paz, H. Grande, E. Pellicer, J. Sort, J. Fornell, R. Offoiach, M. Lekka, E. García-Lecina, Monolayered versus multilayered electroless $\mathrm{NiP}$ coatings: 
Impact of the plating approach on the microstructure, mechanical and corrosion properties of the coatings, Surf. Coatings Technol. 368 (2019) 138-146. doi:10.1016/i.surfcoat.2019.04.013

[16] P. Sahoo, S. K. Das, Tribology of electroless nickel coatings - A review, Mater. Des. 32 (2011) 1760-1775. doi:10.1016/j.matdes.2010.11.013

[17] V. Vitry, F. Delaunois, Nanostructured electroless nickel-boron coatings for wear resistance, in: AntiAbrasive Nanocoatings, Elsevier, Cambridge, 2015. doi:10.1016/B978-0-85709-211-3.00034-0

[18] M. Anik, E. Körpe, E. Şen, Effect of coating bath composition on the properties of electroless nickel-boron films, Surf. Coatings Technol. 202 (2008) 1718-1727. doi:10.1016/j.surfcoat.2007.07.031

[19] A. Biswas, S. K. Das, P. Sahoo, Effect of heat treatment duration on tribological behavior of electroless Ni-(high)P coatings, IOP Conf. Ser. Mater. Sci. Eng. 149 (2016) 012045. doi:10.1088/1757-899X/149/1/012045

[20] S. Kundu, S. K. Das, P. Sahoo, Influence of load and temperature on tribological behaviour of electroless Ni-P deposits, IOP Conf. Ser. Mater. Sci. Eng. 149 (2016) 012046. doi:10.1088/1757-899X/149/1/012046

[21] H. A. Al-Qureshi, M. R. F. Soares, D. Hotza, M. C. Alves, A. N. Klein, Analyses of the fundamental parameters of cold die compaction of powder metallurgy, J. Mater. Proces. Technol. 9 (2007) 417-424. doi:10.1016/j.jmatprotec.2007.08.030
[22] F. Bulbul, The effects of deposition parameters on surface morphology and crystallographic orientation of electroless Ni-B coatings, Met. Mater. Int. 17 (2011) 67-75. doi:10.1007/s12540-011-0210-4

[23] F. Bülbül, L. E. Bülbül, Fabrication of antibacterial and hydrophilic electroless Ni-B coating on 316L stainless steel, Appl. Phys. A 122 (2016) 25. doi:10.1007/s00339-015-9549-6

[24] F. Delaunois, J. P. Petitjean, P. Lienard, M. Jacob-Duliere, Autocatalytic electroless nickel-boron plating on light alloys, Surf. Coatings Technol. 124 (2000) 201-209. doi:10.1016/S0257-8972(99)00621-0

[25] V. Vitry, F. Delaunois, C. Dumortier, Mechanical properties and scratch test resistance of nickel-boron coated aluminium alloy after heat treatments, Surf. Coatings Technol. 202 (2008) 3316-3324. doi:10.1016/j.surfcoat.2007.12.001

[26] F. Delaunois, P. Lienard, Heat treatments for electroless nickel-boron plating on aluminium alloys, Surf. Coatings Technol. 160 (2002) 239-248. doi:10.1016/S0257-8972(02)00415-2

[27] U. Matik, R. Çıtak, Influence of the heat treatment on hardness and adhesive wear performance of Ni-P deposit with low phosphorus content, Mater. Test. 57 (2015) 431-436. doi:10.3139/120.110719

[28] V. Niksefat, M. Ghorbani, Mechanical and electrochemical properties of ultrasonic-assisted electroless deposition of $\mathrm{Ni}-\mathrm{B}-\mathrm{TiO}_{2}$ composite coatings, J. Alloys Compd. 633 (2015) 127-136. doi:10.1016/j.jallcom.2015.01.250 